\title{
Конференция «Школа по теоретической и морской паразитологии»
}

В качестве вступления хочу сказать, что упомянутое в заголовке мероприятие - единственное с такой тематикой не только в отечественной, но и в мировой науке. Вообще, термин «теоретическая» не часто используется по отношению к паразитологии, несмотря на сложность и многогранность этой науки. Напомню известный факт: за более чем двухсотлетнюю историю развития так и не сформулировано ее всеобъемлющее и лаконичное определение.

Нынешняя VII Всероссийская конференция с международным участием «Школа по теоретической и морской паразитологии», как и предыдущая, прошла в комплексе БлагоЛюбоМорье под Севастополем, 9-14 сентября.

На сессии «Современные экологические и эволюционные проблемы теоретической и морской паразитологии» было заслушано 10 пленарных докладов. Д.б.н. К.В. Галактионов (Зоологический институт (ЗИН) РАН) подвел предварительные итоги исследований трематод, циркулирующих в прибрежных экосистемах северных морей, в результате которых оценено их биоразнообразие, дифференцированы близкие виды и расшифрованы жизненные циклы ряда представителей семи семейств. Такие исследования позволяют понять пути и механизмы освоения новых хозяев и регионов в ходе ледниковых циклов и оценить изменения в фауне и биоло-

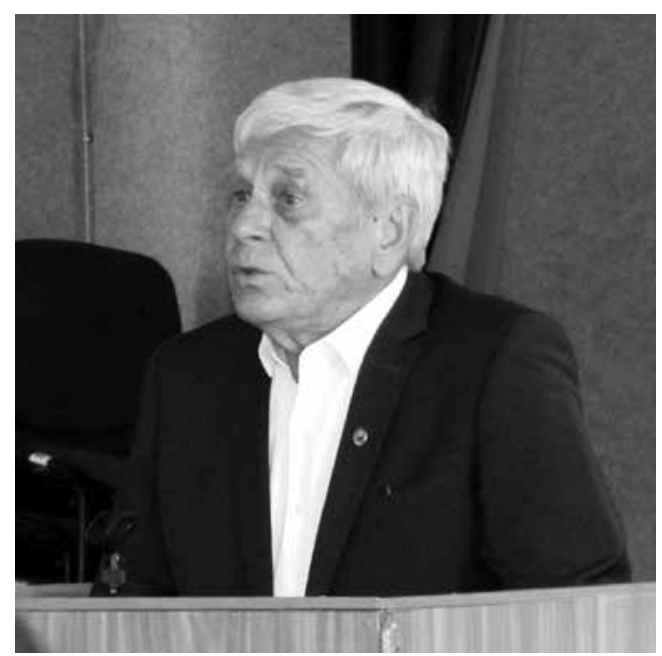

Приветственное слово научного руководителя ИнБЮМ РАН академика РАН В.Н. Егорова. Фото В.П. Никииина гии трематод в условиях происходящего потепления. Д.б.н. В.В. Алешин (Московский государственный университет им. М.В. Ломоносова) на основании анализа молекулярно-генетических данных показал, что ортонектиды и дициемиды представляют собой вторично и независимо упрощенные группы, но с усложненными, в связи с чередованием поколений, жизненными циклами. Д.б.н. С.А. Карпов (ЗИН) проанализировал существующие гипотезы происхождения грибов и пришел к выводу о том, что равно обоснована аргументация их эволюции как от свободноживущих предков, так и от паразитов. По мнению д.б.н. В.П. Никишина (Институт биологических проблем Севера (ИБПС) ДВО РАН), усложнение функциональной нагрузки клеток и тканей гельминтов (мультифункциональность) в одних случаях может быть следствием перехода к паразитизму, в других - отражением естественного процесса эволюции. К.б.н. С.К. Семенова и к.б.н. Г.Г. Хрисанфова (Институт биологии гена РАН) сравнили организацию митохондриальных геномов у 35 видов трематод и показали, что полиморфизм ДНК определяется вариацией протяженных некодирующих последовательностей, содержащих видоспецифичные прямые и инвертированные повторы разных длины и состава. К.б.н. Д.М. Атопкин (ФНЦ Биоразнообразия наземной биоты Восточной Азии ДВО РАН) оценил

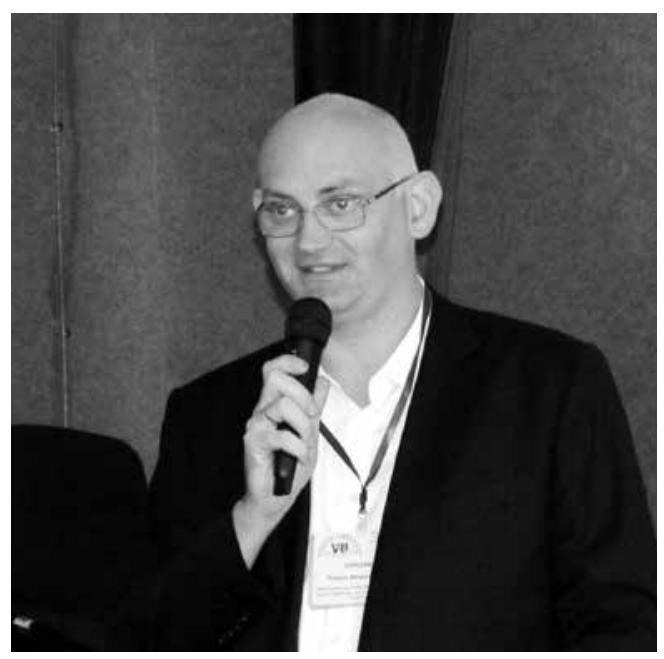

Открытие конференции. Выступает и.о. директора Института биологии южных морей им. А.О. Ковалевского РАН к.г.н. Р.В. Горбунов. Фото В.П. Никииина 
значение морфологических и молекулярных критериев в систематике трематод и пришел к выводу, что следует воздержаться от введения новых таксонов ранга подсемейства и выше до тех пор, пока не будут накоплены молекулярные данные в количестве, необходимом для полноценного анализа, при этом роль морфологии и морфометрии в систематике не должна быть занижена. М.н.с. Е.А. Водясова (Институт биологии южных морей им. А.О. Ковалевского (ИнБЮМ) РАН) эмоционально рассказала о новых технологиях исследований отдельных клеток, открывающих возможности воздействовать на их геном. Д.б.н. А.Ю. Рысс (ЗИН) представил гипотезу эволюции стволовых фитонематод, оригинальный жизненный цикл которых включает пропагативные поколения на растении и грибе и трансмиссивных личинок в насекомом, находящихся на стадии диапаузы. К.б.н. Н.И. Юрлова и м.н.с. Н.М. Пономарёва (Институт систематики и экологии животных (ИСиЭЖ) СО РАН) показали, что годовая продукция и биомасса церкарий - свободноживущих личинок трематод, выделяемых моллюском - в зависимости от вида паразита может достигать (в сухом виде) 37-50 \% от массы моллюска, т.е. сопоставима с массой бентосных беспозвоночных. Д.б.н. Г.Л. Атаев (Российский государственный педагогический университет им. А.И. Герцена (РГПУ)) рассказал об особенностях развития инфрапопуляции трематоды Echinostoma caproni в промежуточном хозяине (моллюске), в частности о высокой смертности зараженных моллюсков в эксперименте, вызванной их вторичной инвазией церкариями и превращением последних в метацеркарии; таким образом, моллюски последовательно выполняют роль первого, а затем второго промежуточного хозяина.

Секция «Биоразнообразие, жизненные циклы, популяционная биология паразитов морских организмов, взаимоотношения в системах паразит-хозяин» оказалась самой представительной. Из 12 заслушан- ных докладов отметим сообщение к.б.н. Ю.М. Корнийчук (ИнБЮМ) о резком и загадочном обеднении фауны трематод рыб в Карадагском природном заповеднике (по истечении 70 лет из 46 ранее отмеченных видов в списке отсутствует уже 21), при этом исчезновение только немногих видов может быть объяснено сокращением численности хозяев. Об особенностях жизненных циклов некоторых гельминтов информировали сотрудники ИБПС: к.б.н. К.В. Регель проанализировала литературные и собственные данные о роли литоральных ракообразных в циркуляции цестод морских уток в северо-западных и северо-восточных акваториях Евразии, к.б.н. Е.И. Михайлова показала, что состояние популяций трех видов скребней рода Neoechinorhynchus в условиях Субарктики зависит как от экологических связей популяций хозяев, так и от температурных адаптаций паразитов.

При анализе докладов, представленных в секции «Молекулярные маркеры в систематике, филогении и экологии паразитов», приходишь к выводу о том, что эйфорию относительно всемогущества молекулярной биологии начинает сменять осознание того, что круг вопросов, на которые она может дать ответы, небезграничен, т.е. наблюдается ситуация, аналогичная сложившейся в последнем десятилетии прошлого века вокруг электронной микроскопии. К.б.н. А.А. Макариков (ИСиЭЖ) в своем анализе гименолепидид отметил, что система этих цестод, основанная на морфологических критериях и гостальной специализации, нуждается в ревизии, однако подчеркнул, что ревизия должна основываться на сочетании морфологического анализа и молекулярно-генетических данных. Такое сочетание морфологических и молекулярно-генетических исследований прослеживалось в докладах м.н.с. Ю.В. Белоусовой с соавторами (ИнБЮМ) в подходе к исследованию личинок трематод в моллюске Pitar rudis из Черного моря, лаборанта А.В. Дюминой (ЗИН) с соавторами о таксономическом статусе нескольких родов акантоцефалов,

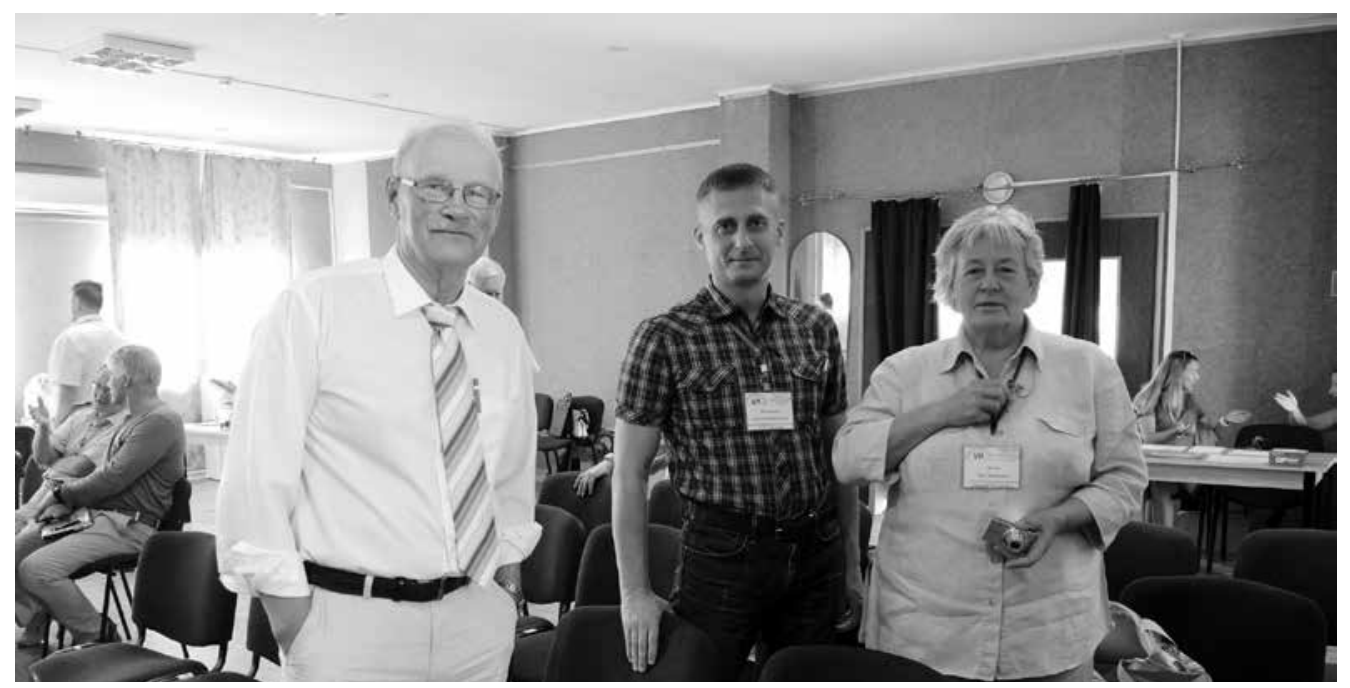

Участники конференции д.б.н. В.П. Никишин (ИБПС ДВО РАН), к.б.н. А.А. Макариков (ИСиЭЖ СО РАН), к.б.н. К.В. Регель (ИБПС ДВО РАН), Фото к.б.н. Н.А. Поспеховой (ИБПС ДВО РАН) 
к.б.н. Е.Е. Прохоровой с соавторами (РГПУ) о морфологической и генетической изменчивости черноморской моногенеи Gyrodactylus sphynx.

Секция «Морфологические аспекты паразитизма» оказалась самой малочисленной, вероятно, ввиду того что ряд морфологических сообщений был представлен в других секциях. К.б.н. А.М. Лях с соавторами (ИнБЮМ) использовал методы анализа контуров в изучении межвидовой и внутривидовой изменчивости моногеней и дифференциации их видов. К.б.н. Н.А. Поспехова (ИБПС) рассмотрела морфологию четырех видов метацестод (цистицеркоидов) из подотряда гименолепидат, изученную методами световой и электронной микроскопии. К.б.н. С.А. Корниенко (ИСиЭЖ) подтвердила независимый статус родов гименолепидидных цестод, образующих самостоятельную трибу.

Секции «Использование паразитов для оценки состояния водных экосистем и в качестве биологических меток при изучении различных сторон экологии хозяев» и «Прикладные аспекты морской паразитологии» были объединены. Отметим работу к.б.н. Н.А. Андреевой (Институт природно-технических систем Министерства образования РФ), изучившей динамику микробиоты в организме больных дельфинов и показавшей ее количественные и качественные изменения как под влиянием факторов среды, так и вследствие ослабления иммунитета. Конференцию завершили мастер-класс д.б.н. А.Ю. Рысса по фитопаразитологии и сессия стендовых докладов. Последняя прошла в неформальной обстановке: докладчики могли выступить у своих стендов с коротким сообщением и ответить на вопросы коллег.

В кулуарах конференции много обсуждали околонаучные проблемы, в частности ситуацию с финансированием научных учреждений и порядок определения эффективности их работы. Относительно первой проблемы было отмечено, что при общем заметном увеличении средств львиная доля их направляется на заработную плату, собственно же научные иссле- дования, включая экспедиции, могут осуществляться только за счет грантов (преимущественно РФФИ), количество которых, однако, с каждым годом сокращается. Что касается наукометрии, то здесь многие коллеги критиковали популярное в последние годы объединение научных журналов в так называемые квартили, причем принципы объединения неясны (например, некоторые журналы из третьего квартиля имеют импакт-фактор выше, чем журналы из второго). Уместно будет вспомнить мнение Нобелевского лауреата по медицине 2013 г. Рэнди Шекмана, который в своей Нобелевской речи заявил, что ведущие научные журналы ориентированы на коммерческий успех, а не на развитие науки, и пообещал больше не отправлять свои статьи в «Nature», «Cell», «Science» и им подобные.

Помимо отечественных, в работе конференции участвовали ученые из Азербайджана, Белоруссии, Вьетнама, Казахстана, Польши, Турции. Всего было заслушано 55 докладов и представлено более 20 стендовых сообщений. Как и предыдущая, состоявшаяся в 2016 г., нынешняя конференция отличалась прекрасной организацией, доброжелательным отношением организаторов (администрация ИнБЮМ и коллектив отдела экологической паразитологии), насыщенной экскурсионной программой. Следующую, восьмую, Школу по теоретической и морской паразитологии было предложено провести в 2021 г. на базе Карадагского природного заповедника.

В.П. НИКИШИН, доктор биологических наук, главный научный сотрудник (Институт биологических проблем Севера ДВО РАН, Северо-Восточный государственный университет, Магадан). E-mail:nikishin@ibpn.ru 